\title{
RAPID IN VITRO CALLOGENESIS AND PHYTOCHEMICAL SCREENING OF LEAF, STEM AND LEAF CALLUS OF MUSSAENDA FRONDOSA LINN.: A MEDICINAL PLANT
}

\author{
MANASA DJ, CHANDRASHEKAR KR*, BHAGYA N \\ Department of Applied Botany, Mangalore University, Mangalagangothri, Mangalore - 574 199, Karnataka, India. \\ Email: profkrchandrashekar@gmail.com
}

Received: 06 February 2017, Revised and Accepted: 08 March 2017

\section{ABSTRACT}

Objective: To standardize the protocol for rapid callogenesis in Mussaenda frondosa L. using leaf explants. Qualitative and quantitative phytochemical analysis of leaf, stem, and callus cultures.

Methods: The leaf explants were inoculated onto Murashige and Skoog medium supplemented with varying concentrations of growth regulators such as 2, 4-D, NAA, benzylaminopurine, Kn for the induction of callus. Qualitative and quantitative analysis of total phenol, flavonoid and alkaloid contents of leaf, stem, and callus were tested by standard methods. The antioxidant activities were investigated using 1, 1- diphenyl-2-picryl hydrazyl radical scavenging method and reducing power assay. The anti-inflammatory activity was evaluated by membrane stabilizing activity.

Results: Pale green, healthy, friable, and fast growing callus were obtained on the medium enriched with NAA (2 mg/l)+Kn (4 mg/l). Quantitative determination showed the highest concentration of total phenolics in the methanolic extract of in vitro grown callus (10 \pm 1.1 mg of GA/g of extract), flavonoids in methanolic stem extract $(137 \pm 1.6 \mathrm{mg}$ of quercitin/g of extract) and alkaloids in methanolic extract of leaf $(118.3 \pm 1.5 \mathrm{mg} / 10 \mathrm{~g}$ of extract). The methanolic leaf extract exhibited the highest free radical scavenging activity with an inhibitory concentration $50 \%$ (IC ${ }_{50}$ ) value of $40.6 \pm 10.06 \mu \mathrm{g} / \mathrm{ml}$. The highest membrane stabilizing activity was shown by chloroform extract of the leaf $(66.02 \%)$.

Conclusion: This preliminary phytochemical and pharmacological analysis may form the basis for drug development in future using callus cultures of $M$. frondosa.

Keywords: Mussaenda frondosa, Antioxidant, Anti-inflammatory, In vitro culture, Phenolics, Flavonoids, Alkaloids.

(C) 2017 The Authors. Published by Innovare Academic Sciences Pvt Ltd. This is an open access article under the CC BY license (http://creativecommons. org/licenses/by/4. 0/) DOI: http://dx.doi.org/10.22159/ajpcr.2017.v10i6.17527

\section{INTRODUCTION}

Plant products contain a large number of pharmacologically active compounds which are being used in traditional medicine since Vedic era. These can be derived from bark, leaves, flowers, roots, fruits, and seeds [1]. Synthetic drugs and antibiotics are found to have many adverse effects and sometimes fatal. Hence, medicinal plants from natural flora are being explored for the synthesis of commercial drugs [2]. Demand for plant products has been increased with increasing population causing depletion of medicinal plants in the natural habitat. The plant tissue culture techniques proved to be an alternative for the production of valuable phytochemicals [3]. Considering the potential and promises of plant cell/tissue culture technology, efforts have been made to improve the productivity of pharmacologically important plant species [4].

Plant cell cultures offer an alternative source to the whole plant for the production of high-value secondary metabolites [5]. Researchers have endeavored to utilize plant cell biosynthetic capabilities for obtaining useful products and for studying the metabolism [6]. A large number of metabolites such as alkaloids, saponins, cardenolides, anthraquinones, polyphenols, and terpenes have been reported from in vitro cultures for e.g. flavonoids and stilbenes [7], sterols [8], cardenolides [9], and phenolic acids [10]. Several strategies have been adopted for the enhancement of in vitro bioactive metabolite production; one such method is, use of growth regulators which is often a crucial factor in secondary product accumulation [11].

Mussaenda frondosa syn. Mussaenda glabrata (Family: Rubiaceae) is a rambling shrub seen in the Western Ghats, Andamans, Konkan, Malabar and Tirunelveli hills. The foliage is lighter green, and the terminal flower clusters have orange to yellow, tubular corollas with a single white enlarged calyx lobe. This species is often grown in clumps [12]. Traditionally, leaves are used in the treatment of jaundice, asthma, hyperacidity, fever, ulcers, leprosy, wound, swells [13] and as an antimicrobial agent [14]. This plant has been investigated by several workers for diuretic [15], hepatoprotective [16], hypolipidemic activities [17], radical scavenging [18] and to treat fever, asthma, and cough. Siju et al. [19] have reported the anthelmintic activity of the ethyl alcohol and aqueous extract of the plant. Flowers are used in detoxifying mushroom poisons and terminate an early pregnancy [20]

Iridoids, flavonoids, and triterpenes are the important bioactive compounds distributed in Mussaenda species. Phytochemicals such as astragalin, isoquercetrin, and kaempferol-3-o-beta rutinoside were isolated from leaves [21]. A new compound sanzhilactone along with mussaenside, barlerin, lupeol and beta-d-glucose has been obtained from the stem [22]. Quercetin (QE), rutin, hyperin, ferulic acid, synaptic acid, beta-sitosterol, saponins have also been isolated [23]

Reports are available on the in vitro callus culture of Mussaenda erythrophylla cvs. [24]. As per the available literature, there are no reports available on the in vitro callogenesis of $M$. frondosa. Therefore, in this work, the effect of phytohormone combinations on the in vitro callus production of $M$. frondosa was investigated, and in vitro experiment was conducted to determine antioxidant and anti-inflammatory effect of leaf, stem, and callus extracts of $M$. frondosa. 


\section{METHODS}

\section{Plant material and surface sterilization}

The leaves of $M$. frondosa were collected from natural forests of Dakshina Kannada district, Karnataka, India. The collected materials were identified following the flora of Udupi and Dakshina Kannada [25]. A voucher specimen (MU/AB/DJM - 02) has been deposited in herbarium collection at Department of Applied Botany, Mangalore University.

The mature, young and the youngest leaf samples were collected to find out the suitability of explants for in vitro callus induction. The fresh and healthy leaves were washed thoroughly under running tap water for $1 \mathrm{hr}$ to remove the surface debris. The leaves were surface sterilized by $1 \%$ bavistin for $1 \mathrm{hr}$ followed by treating with $70 \%$ alcohol for 1 minute and $0.1 \%$ mercuric chloride for 1 minute after each step, the explants were rinsed thoroughly with sterile distilled water. Later, the explants were cut into $1 \mathrm{~cm}^{2}$ and inoculated onto Murashige and Skoog (MS) medium [26] at $25 \pm 2^{\circ} \mathrm{C}$ and a photoperiod of $16 \mathrm{hrs} \mathrm{light} \mathrm{and} 8 \mathrm{hrs}$ dark for 30 days. Observations like a percentage (\%) of browning, fungal contamination; bacterial contamination and explants survival rate were made until 3 weeks of inoculation.

\section{Callus induction}

The sterilized young leaf explants were inoculated onto MS medium fortified with different concentrations of growth regulators such as 2,4-dichlorophenoxyacetic acid (2, 4-D), -naphthaleneacetic acid (NAA), benzylaminopurine (BAP), and Kinetin (KN) for the induction of callus (Table 1). All the cultures were incubated at $25 \pm 2^{\circ} \mathrm{C}$ with $16 \mathrm{hrs}$ of photoperiod and $40.0 \pm 3.0 \mathrm{mMm}^{2} \mathrm{~s}^{-1}$ light intensity. Twenty explants were inoculated to each combination of growth regulators with one explant per test tube and replicated 3 times. The explants were observed at regular intervals for various details such as the development, color, and texture of callus. The calli were subcultured at 3 weeks of intervals.

\section{Preparation of the plant and callus crude extract}

The dried leaf, stem samples of $M$. frondosa were coarsely powdered and were extracted with methanol, chloroform, dichloromethane (DCM) and water by Soxhlet extraction for $36 \mathrm{hrs}$. The extracts obtained were evaporated to dryness and were stored in the fridge until further use.

Callus was dried in oven at $50^{\circ} \mathrm{C}$ till constant weight was achieved. It was then coarsely powdered using mortar and pestle and extracted in methanol, chloroform, DCM and water in Soxhlet apparatus for $36 \mathrm{hrs}$. The extracts were concentrated till dry and were stored in the fridge for future analysis.

\section{Qualitative and quantitative analysis of total phenol, flavonoid,} and alkaloid contents

The leaf, stem, and in vitro grown callus extracts were subjected to preliminary phytochemical screening to determine the presence of secondary metabolites such as alkaloids, flavonoids, terpenoids, phenols, tannins, and glycosides by standard methods [27,28]. Total phenolic, flavonoid, and alkaloid contents in the crude extract were determined as per Harborne [27], Ikram et al. [29], and Sreevidya and Mehrotra [30], respectively. Free radical scavenging activities of the extracts were determined using 1, 1-diphenyl-2-picryl hydrazyl radical (DPPH) as per Zishen et al. [31] and the reducing power by the method of Oyaizu [32]. Anti-inflammatory activity was determined by membrane stabilizing activity as per Shinde et al. [33].

\section{Solvents and chemicals}

All the chemicals used were of analytical grade procured from Sigma-Aldrich. The growth regulators were obtained from Hi-Media.

\section{Statistical analysis}

Experiments were repeated thrice $(n=3)$. Data were analyzed by SPSS statistical package software version 20 with Duncan's multiple range test grouping. Statistical differences were considered significant at ${ }^{*} \mathrm{p}<0.05$
Table 1: Effects of PGRs on callus induction and callus growth of leaf segments of $M$. frondosa

\begin{tabular}{|c|c|c|c|c|}
\hline PGRs & $\begin{array}{l}\text { Concentration } \\
\text { of PGRs (mg/l) }\end{array}$ & $\begin{array}{l}\% \text { of callus } \\
\text { induction }\end{array}$ & $\begin{array}{l}\text { Response } \\
\text { intensity } \\
\text { of callus }\end{array}$ & $\begin{array}{l}\text { Texture } \\
\text { of callus }\end{array}$ \\
\hline Control & - & 0 & - & - \\
\hline \multirow{4}{*}{$\mathrm{MS}+2,4-\mathrm{D}$} & 0.5 & 50 & + & Friable \\
\hline & 1 & 68 & ++ & \\
\hline & 2 & 75 & ++ & \\
\hline & 3 & 78 & ++ & \\
\hline \multirow[t]{4}{*}{$\mathrm{MS}+\mathrm{NAA}$} & 0.5 & 50 & + & Friable \\
\hline & 1 & 75 & ++ & \\
\hline & 2 & 90 & ++++ & \\
\hline & 3 & 90 & ++++ & \\
\hline \multirow{4}{*}{$\mathrm{MS}+\mathrm{BAP}$} & 0.5 & 80 & + & Friable \\
\hline & 1 & 70 & ++ & \\
\hline & 2 & 60 & ++ & \\
\hline & 3 & 54 & ++ & \\
\hline \multirow[t]{4}{*}{$\mathrm{MS}+\mathrm{Kn}$} & 0.1 & 20 & + & Friable \\
\hline & 0.5 & 70 & ++ & \\
\hline & 1 & 50 & + & \\
\hline & 1.5 & 55 & + & \\
\hline \multirow[t]{4}{*}{$\mathrm{MS}+2,4 \mathrm{D}+\mathrm{Kn}$} & $0.5+0.1$ & 20 & + & Friable \\
\hline & $1+0.5$ & 45 & + & \\
\hline & $2+1$ & 65 & ++ & \\
\hline & $3+2$ & 80 & ++ & \\
\hline \multirow[t]{4}{*}{$\mathrm{MS}+2,4 \mathrm{D}+\mathrm{BAP}$} & $0.5+0.1$ & 60 & ++ & Friable \\
\hline & $1+0.5$ & 80 & +++ & \\
\hline & $2+1$ & 90 & ++++ & \\
\hline & $3+2$ & 90 & ++++ & \\
\hline \multirow[t]{4}{*}{$\mathrm{MS}+\mathrm{NAA}+\mathrm{BAP}$} & $0.1+1$ & 50 & + & Friable \\
\hline & $0.5+2$ & 60 & ++ & \\
\hline & $1+3$ & 90 & ++++ & \\
\hline & $2+4$ & 90 & ++++ & \\
\hline \multirow[t]{4}{*}{$\mathrm{MS}+\mathrm{NAA}+\mathrm{Kn}$} & $0.1+1$ & 60 & ++ & Friable \\
\hline & $0.5+2$ & 80 & +++ & \\
\hline & $1+3$ & 90 & ++++ & \\
\hline & $2+4$ & 90 & ++++ & \\
\hline
\end{tabular}

+: Poor response, ++: Moderate response, +++: Good response, ++++: Very goo response, PGRs: Plant growth regulators, M. frondosa: Mussaenda frondosa, MS: Murashige and Skoog, NAA: 1-naphthaleneacetic acid

\section{RESULTS AND DISCUSSION}

\section{Callus induction and establishment}

Young leaf segments were transferred to different media for induction of callus expanded on all media after 4-5 days of inoculation. Calli were developed from the cut surfaces of the leaf, midrib regions and also from the surface of explants. All the combinations of growth hormones showed the development of callus in varying percentage. The maximum rate of callus proliferation was obtained on MS medium supplemented with different combinations of growth hormones such as NAA (2 mg/L)+BAP (4 mg/L) (Fig. 1a), 2,4-D (2 mg/L)+BAP $(1 \mathrm{mg} / \mathrm{L})$ (Fig. 1b) 2 and $3 \mathrm{mg} / \mathrm{L} \mathrm{NAA} \mathrm{(Fig.} \mathrm{1c),} \mathrm{NAA}(2 \mathrm{mg} / \mathrm{L})+\mathrm{Kn}$ ( $4 \mathrm{mg} / \mathrm{L})$ (Fig. 1d), 2,4-D (3 mg/L)+BAP (2 mg/L), NAA (1 mg/L)+BAP (3 mg/L), and NAA (1 mg/L)+Kn (3 mg/L) (Table 1). Compact yellow callus produced on the MS media supplemented with different concentrations of kinetin (0.1-1.5 mg/L) showing a poor response. NAA, at all concentrations, produced friable callus which turned brown after subculturing (Fig. 1e). Callus developed on MS media with 2,4-D+BAP, $\mathrm{NAA}+\mathrm{BAP}$, and NAA (1 mg/L)+Kn (3 mg/L) was slow growing, turned brown and failed to proliferate after subculturing after 3-4 weeks. Since NAA ( $2 \mathrm{mg} / \mathrm{L})+\mathrm{Kn}(4 \mathrm{mg} / \mathrm{L})$ was found to be the best for callus induction with pale green, healthy, friable, and fast growing this was selected for further experiments.

MS medium supplemented with $1.0 \mathrm{mg} / \mathrm{L} \mathrm{BA}$ and $2.0 \mathrm{mg} / \mathrm{L}$ indole-3acetic acid (IAA) was found to be best suitable for callus proliferation in Mussaenda erythrophylla cv [24]. Combination of 2, 4-D (1 mg/L) 
with BA $(0.5 \mathrm{mg} / \mathrm{l})$ for callus induction was reported in Plumbago zeylanica [34]. Bhagya and Chandrashekar [35], proved MS medium with NAA+BAP $(1+0.1 \mathrm{mg} / \mathrm{L})$ gave the best results for callus induction in Justicia gendarussa Burm. f.

Preliminary phytochemical analysis of $M$. frondosa leaf, stem, and callus extract shown in Table 2. Phenolics, flavonoids, alkaloids and glycosides detected in leaf, stem and callus extracts. Tannins and triterpenoids were found to be absent in leaf. Chloroform extract of stem and callus indicated the presence of all the phytochemicals tested except for triterpenoids, steroids, and resins. Chloroform extract of leaf, stem, and callus showed a maximum number of phytochemicals tested. Similar results were obtained in the phytochemical screening of the Tecoma stans leaves extracted in different solvents [36], whereas Thalwal et al. found methanol to be the better solvent for the extraction of phytochemicals in Amaranthus spinosus [37]. These phytochemicals are responsible for various biological activities. The importance of these metabolites in treating various diseases reported by Kubmarawa et al. [38] and Mensah et al. [39].

Varying concentrations of phenol, flavonoid and alkaloid contents were detected in leaf, stem, and callus of $M$. frondosa extracts. The highest concentration of total phenolics was present in the methanolic extract of in vitro grown callus (10 $\pm 1.1 \mathrm{mg}$ of GA/g of extract) (Fig. 2). The phenolic content in the leaf and stem extracts ranged between $1.7 \pm 0.2$ and $6.5 \pm 0.2 \mathrm{mg}$ of $\mathrm{GA} / \mathrm{g}$ of extract and $3.5 \pm 0.3$ to $6.5 \pm 0.3 \mathrm{mg}$ of GA/g of extract, respectively whereas, in callus extract it was found in the range between $1.4 \pm 0.5$ and $10 \pm 1.1 \mathrm{mg}$ of $\mathrm{GA} / \mathrm{g}$ of extract. Similar results were reported in J. gendarussa Burm. f [35], Alangium salviifolium [40] and Cyclea peltata [41]. The effect of growth regulators on the biosynthesis of phenolic compounds was studied in hairy roots of Panax ginseng by Jeong et al. [42]. Taj Al-Deen [43] recorded low value of total phenolic content $128.67 \mathrm{mg} / \mathrm{g}$ of dry weight of an alcoholic extract of callus derived from hypocotyls of Trigonella foenum-graecum compared to plant parts. The solvent system plays an important role in the solubility of phytochemical components in the crude extracts [44]

This study showed maximum flavonoid content in the stem extracts when compared to leaf and callus extract (Fig. 3). Methanolic stem extract possesses significantly the highest amount of flavonoid content $(137 \pm 1.6 \mathrm{mg}$ of $\mathrm{QE} / \mathrm{g}$ of extract). Total flavonoid content in the leaf ranged between $35.3 \pm 1.5$ and $53.8 \pm 1.7 \mathrm{mg}$ of $\mathrm{QE} / \mathrm{g}$ of extract. In callus extract, the total flavonoid ranged between $12.4 \pm 1.4$ and $76 \pm 1 \mathrm{mg}$ of $\mathrm{QE} / \mathrm{g}$ of extract, with a highest in the methanolic extract. Umesh [45], spectrophotometrically determined total flavonoids in methanolic extract of Decalepis hamiltonii (Wight and Arn) in roots and callus as $180.5 \pm 63.36 \mu \mathrm{g}(\mathrm{QE}) / \mathrm{mg}$ and $130.6 \pm 3.571 \mu \mathrm{g}(\mathrm{QE}) / \mathrm{mg}$ of extract, respectively. Rami and Patel [46] found maximum flavonoid content of $1.025 \pm 0.002 \mathrm{mg} / \mathrm{g}$ in methanolic extract of in vitro developed root when compared to wild plant and other in vitro plant parts.
It is well known that the concentrations of phenolic content are usually higher than the concentrations of flavonoid in most cases, but a reverse trend was observed in this study. It can be explained by the fact that differences in the polarity of the phytochemicals toward different solvents used in the experiment. Furthermore, it is well known that the Folin-Ciocalteu method is a rapid and widely used assay to detect the total phenolic content, but different phenolic compounds have different responses in the Folin-Ciocalteu method [47].

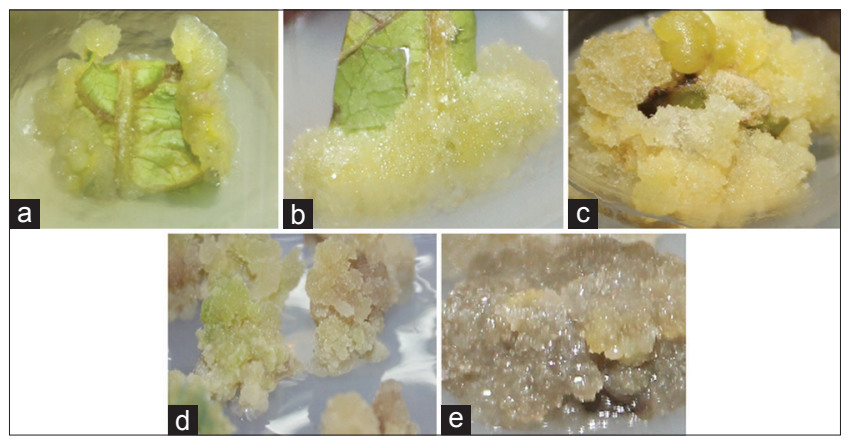

Fig. 1: In vitro callus induction from leaf explants of Mussaenda frondosa. Callus initiation from the leaf explant grown on Murashige and Skoog (MS) mediun supplemented with (a) NAA (2 mg/L) + benzylaminopurine (BAP) (4 mg/L). (b) 2, 4-D (2 mg/L)+BAP (1 mg/L). (c) NAA (2 mg/L). (d) Subcultured callus on MS medium supplemented with NAA ( $2 \mathrm{mg} / \mathrm{L})+\mathrm{Kn}$

( $4 \mathrm{mg} / \mathrm{L}$ ). (e) Callus turned brown after subculturing to MS media supplemented with NAA (3 mg/L)

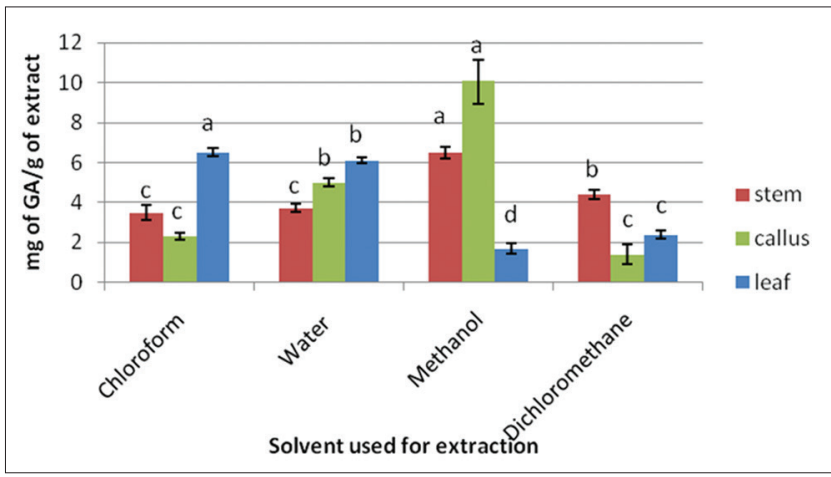

Fig. 2: Comparative analysis of total phenols present in leaf, stem and callus of Mussaenda frondosa. Values are mean \pm standard deviation each of three replicates $(n=3)$. Different alphabets indicate significant difference at ${ }^{*} \mathrm{p}<0.05$

Table 2: Preliminary phytochemical screening of $M$. frondosa leaves, stem, and callus

\begin{tabular}{|c|c|c|c|c|c|c|c|c|c|c|c|c|}
\hline \multirow{3}{*}{$\begin{array}{l}\text { Phytochemicals } \\
\text { Extract } \\
\end{array}$} & \multicolumn{12}{|c|}{ M. frondosa } \\
\hline & \multicolumn{4}{|l|}{ Leaf } & \multicolumn{4}{|l|}{ Stem } & \multicolumn{4}{|c|}{ Callus } \\
\hline & CHL & WAT & MET & DCM & CHL & WAT & MET & DCM & CHL & WAT & MET & DCM \\
\hline Phenols & + & - & + & + & + & - & + & + & + & - & - & + \\
\hline Flavonoids & + & + & + & + & + & + & + & + & + & - & + & + \\
\hline Tannins & - & - & - & - & + & - & - & - & + & - & - & - \\
\hline Saponins & + & - & - & + & + & + & - & - & + & + & - & - \\
\hline Alkaloids & + & - & + & + & + & - & - & + & + & - & - & + \\
\hline Glycosides & + & + & + & + & + & + & + & - & + & + & + & + \\
\hline Triterpenoids & - & - & - & - & - & - & - & - & - & - & - & - \\
\hline Resins & + & - & + & + & - & - & - & - & + & - & - & + \\
\hline Steroids & + & - & + & + & - & + & - & - & + & + & + & + \\
\hline
\end{tabular}

CHL: Chloroform, WAT: Water, MET: Methanol, DCM: Dichloromethane, (+): Present, (-): Absent, M. frondosa: Mussaenda frondosa 
A significantly higher yield of $118.3 \pm 1.5 \mathrm{mg} / 10 \mathrm{~g}$ of alkaloid was observed in methanolic extract of the leaf (Fig. 4). Leaf extracts showed the alkaloid content ranging from $118.3 \pm 1.5$ to $21.6 \pm 1.3 \mathrm{mg} / 10 \mathrm{~g}$ of extract. The alkaloid content in the callus extract is between $104.5 \pm 1.5$ and $98 \pm 1.2 \mathrm{mg} / 10 \mathrm{~g}$ of extract, and in stem extract it is between $106.4 \pm 1.5$ and $60.4 \pm 1.8 \mathrm{mg} / 10 \mathrm{~g}$ of extract. Similar results were obtained in Leonurus heterophyllus Sw., [48]. In contrast, enhanced accumulation of total alkaloids was observed in vitro grown callus of Withania somnifera [49].

\section{Antioxidant activity}

Methanolic extractofleafand callus showedan on parDPPH reducingactivity with an inhibitory concentration $50 \%\left(\mathrm{IC}_{50}\right.$ ) value of $40.6 \pm 10.06 \mu \mathrm{g} / \mathrm{ml}$ and $52 \pm 11.35 \mu \mathrm{g} / \mathrm{ml}$, respectively (Fig. 5). Similar results were obtained in D. hamiltonii (Wight and Arn), in which the radicle scavenging activity was highest in root extract when compared to the in vitro grown callus with an $\mathrm{IC}_{50}$ values of $20 \pm 1.54$ and $148 \pm 4.39 \mu \mathrm{g} / \mathrm{ml}$, respectively. However, the $\mathrm{IC}_{50}$ value for stem extract was much higher compared to leaf and callus. The free radical scavenging activity of the standard ascorbic acid was found to be more than the extracts with an $\mathrm{IC}_{50}$ value of $15 \mu \mathrm{g} / \mathrm{ml}$. In contrary, the highest DPPH scavenging activity was recorded in the in vitro grown callus than the plant parts by Babeet et al. [50] in A. salviifolium Linn. and Bhagya and Chandrashekar [35] in J. gendarussa Burm. f.

The reducing power of a compound may serve as a significant reflection of antioxidant activity, as they protect the system by the damaging effect of reactive oxygen species like hydroxyl radical. The reducing ability of a compound depends on the presence of reductants [51], which have been exhibited antioxidative potential by breaking the free radical chain, donating a hydrogen atom [52].

The extracts of $M$. frondosa showed concentration-dependent reducing power. The highest reductive capacity was observed in the methanolic extracts of the samples tested. Higher absorbance value indicates a stronger reducing power of the samples (Fig. 6). Antioxidant compounds can donate electrons to reactive radicals, reducing them into more stable and unreactive species [53].

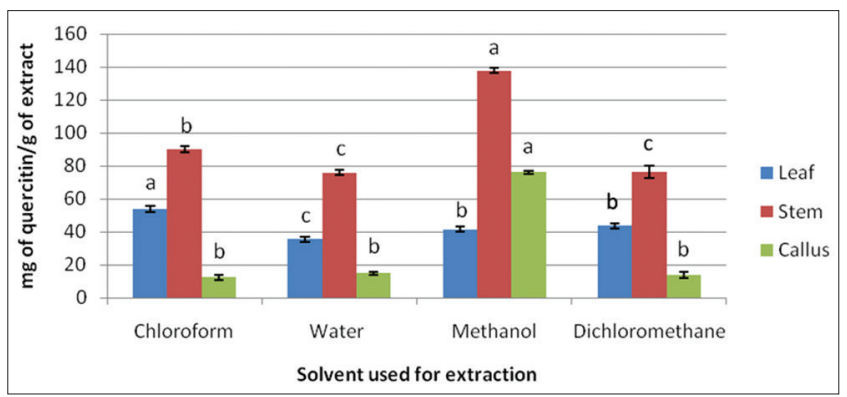

Fig. 3: Comparative analysis of total flavonoids present in the stem, leaf and callus of Mussaenda frondosa. Values are mean \pm standard deviation each of three replicates $(n=3)$.

Different alphabets indicate significant difference at ${ }^{*} \mathbf{p}<0.05$

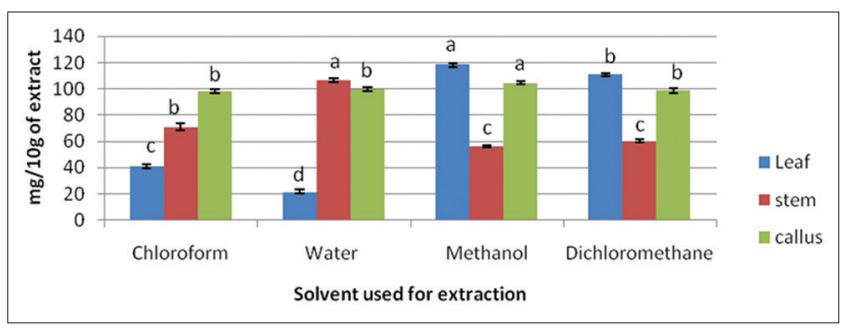

Fig. 4: Comparative analysis of total alkaloids present in the stem, leaf and callus of Mussaenda frondosa. Values are mean \pm standard deviation each of three repeats $(n=3)$. Different alphabets indicate significant difference at $* p<0.05$
Anti-inflammatory activity

The effect of extracts of all the parts on the stabilization of human red blood cell (HRBC) membrane shown in Table 3. Chloroform extract of leaf, stem, and callus extracts showed $66.02 \%, 53.86 \%$, and $65.91 \%$ HRBC membrane stabilization activity, respectively. Deepika and Vidya [54] reported a similar result where the maximum stabilization percentage was obtained in the leaf extracts of Pluchea lanceolata Oliver and Hiern $(86.8 \%$ at $1000 \mu \mathrm{g} / \mathrm{ml})$ as compared to stem, root, and callus samples. Deepika et al. [55] also reported the maximum stabilization percentage in leaves $(88.8 \%$ at a dose of $1000 \mu \mathrm{g} / \mathrm{ml}$ ) compared to stem and callus samples in Cocculus hirsutus (L.) Diels. Contrary results were reported by Taylor and Van Staden [56] in the plant Eucomis autumnalis (Mill.) Chitt. However, the extracts showed the lower membrane stabilization activity when compared to the standard drug diclofenac - sodium which showed $70.14 \%$ stabilization.

\section{CONCLUSION}

Medicinal plants form a large group of economically important plants that provide the necessary raw materials for indigenous pharmaceuticals. Results of the phytochemical evaluation of different extracts of $M$. frondosa revealed the presence of alkaloids, flavonoids, phenols, glycosides, saponins, and steroids. The pharmacological screening of leaf, stem, and callus extracts showed good antioxidant and anti-inflammatory activity. Hence, the callus cultures producing antioxidant and anti-inflammatory compounds might serve as model systems to investigate the regulation and production of these essential metabolites. The study will provide an efficient in vitro protocol for callus induction for the production

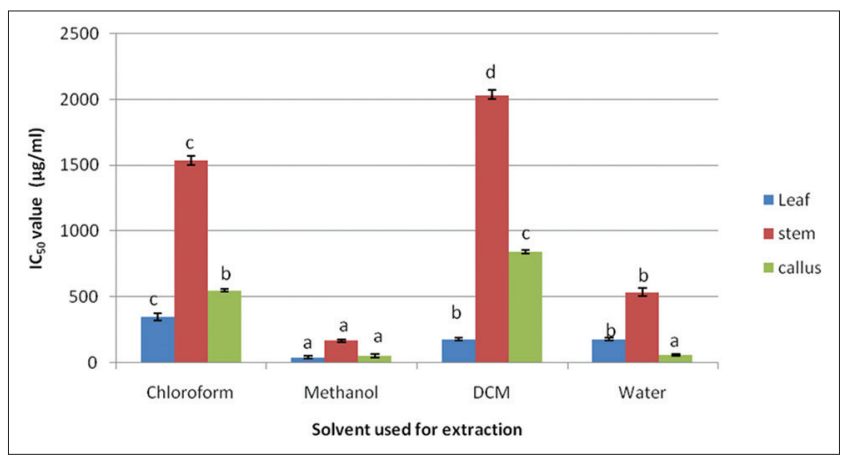

Fig. 5: The inhibitory concentration $50 \%$ value of leaf, stem and in vitro grown callus of Mussaenda frondosa. Values are mean \pm standard deviation each of three replicates $(n=3)$. Different alphabets indicate significant difference at ${ }^{*} \mathbf{p}<0.05$

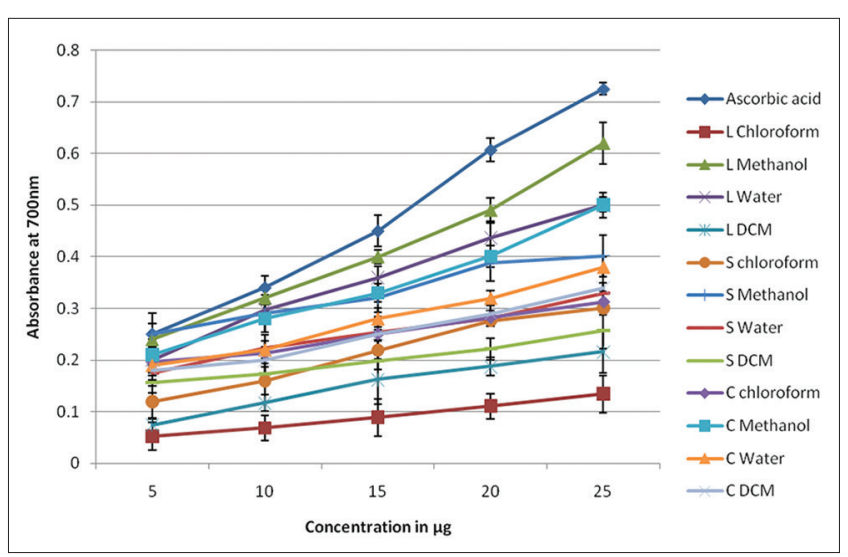

Fig. 6: Reducing power assay of leaf, stem and callus of Mussaenda frondosa. L - Leaf, S - Stem, C - Callus, DCM - Dichloromethane. Values are mean \pm standard deviation each of three repeats $(n=3)$ 
Table 3: Effect of leaf, stem, and callus extracts of $M$. frondosa on anti-inflammatory activity by HRBC membrane stabilization

\begin{tabular}{llll}
\hline Solvent & \multicolumn{3}{l}{$\begin{array}{l}\text { HRBC membrane stabilization (in \% } \\
\text { at } \mathbf{1 0 0} \boldsymbol{\mu g} / \mathbf{L} \text { ) }\end{array}$} \\
\cline { 2 - 4 } & Leaf & Stem & Callus \\
\hline Chlorform & 66.02 & 53.86 & 65.91 \\
Methanol & 18.24 & 43.86 & 48.42 \\
DCM & 21.4 & 33.64 & 32.87 \\
Water & 54.47 & 12.87 & 40.64 \\
Standard & 70.14 & & \\
Diclofenac sodium & & & \\
\hline
\end{tabular}

HRBC: Human red blood cell, M. frondosa: Mussaenda frondosa,

DCM: Dichloromethane

of bioactive molecules. If appropriate strategies developed, there will be possibilities of making plant cell factories for the enhanced production of bioactive molecules, which may reduce the pressure on the natural plant resources.

\section{ACKNOWLEDGMENTS}

One of the authors (Manasa DJ) would like to acknowledge DST for inspire fellowship.

\section{REFERENCES}

1. Cragg GM, Newman DJ. Natural product drug discovery in the next millennium. Pharm Biol 2001;39 Suppl 1:8-17.

2. Sirigiri CK, Kokkanti M. In vitro analysis of cytotoxicity and 5- lipoxygenase inhibition activity by using callus extract of Biophytum sensitivum (Linn) DC. Int J Pharm Sci Rev Res 2014;34:215-8.

3. Havkin FD, Leustek T. Plant tissue culture for production of secondary metabolites. Food Technol 1997;51(11):56-61.

4. Sirigiri CK, Kokkanti M, Challa SR. In vitro pharmacological investigations of using leaf callus extracts of Canthium parviflorum Lam. Br Biotechnol J 2014;4(3):325-38.

5. Alfermann AW, Petersen M. Natural products formation by plant cell biotechnology: Results and perspectives. Plant Cell Tissue Organ Culture 1995;43:199-205.

6. Verpoorte R, Contin A, Memelink J. Biotechnology for the production of plant secondary metabolites. Phytochem Rev 2002;1(1):13-25.

7. Maneechai S, De-Eknamkul W, Umehara K, Noguchi H, Likhitwitayawuid K. Flavonoid and stilbenoid production in callus cultures of Artocarpus lakoocha. Phytochemistry 2012;81:42-9.

8. Loredo-Carrillo SE, Santos-Diaz M, Layva E. Establishment of callus from Pyrostegia venusta (Ker Gawl) Miers and effect of abiotic stress on flavonoids and sterols accumulation. J Plant Biochem Biotechnol 2013;22(3):312-8.

9. Sahin G, Verma SK, Gurel E. Calcium and magnesium elimination enhances accumulation of cardenolides in callus cultures of endemic Digitalis species of Turkey. Plant Physiol Biochem 2013;73:139-43.

10. Szopa A, Ekiert H. Production of biologically active phenolic acids in Aronia melanocarpa (Michx.) Elliott in vitro cultures cultivated on different variants of the Murashige and Skoog medium. Plant Growth Regul 2014;72(1):51-8.

11. Duangporn P, Siripong P. Effect of auxin and cytokinin on phyllanthusol a production by callus cultures of Phyllanthus acidus Skeels. Am Eurasian J Agric Environ Sci 2009;5(2):258-63

12. Huxley AM, Levy M. The New Royal Horticultural Society Dictionary of Gardening. Vol. 3. New York: Groves Dictionaries, Inc.; 1999. p. 271-2.

13. Kirtikar KR, Basu BD. Indian Medicinal Plants. $2^{\text {nd }}$ ed. Dehradun: International Book Distributors; 1987.

14. Jain SK. Dictionary of Indian Folk Medicine and Ethno Botany. New Delhi: Deep Publication; 1991.

15. Roshishaliya AP, Kumar U, Upwar N, Patel N. Diuretic study of ethanolic and aqueous extract of Mussaenda frondosa Linn. in normal rats. Available from: http://www.scientificipca.org.

16. Sambrekar SN, Patil PA, Kangralkar VA, Protective activity of Mussaenda frondosa Linn leaf extract against paracetamol induced hepatic damage in wistar rats. J Pharm Res 2010;3(4):711.

17. Wesley JJ, Jeyaananath J, Mohammed AA, Ravikumar K.
Hypolipidemic effect of methanolic extract of Mussaenda frondosa Linn. leaves in high fat diet fed rats. J Pharm Res 2009;2(4):579-81.

18. Koul S, Chaudhary A. Radical scavenging and antistress activity of Mussaenda frondosa Linn roots (Rubiaceae). Pharmacologyonline 2011;1:1091-7.

19. Siju EN, Rajalakshmi GR, Hariraj N, Sreejith KR, Sudhakaran S, Muneer EK, et al. In-vitro anthelmintic activity of Mussaenda frondosa. Res J Pharm Technol 2010;3(1):151-3.

20. Anonymous. Dictionary of Chinese Traditional Medicine. Shanghai: Jiangsu New Medical College, Shanghai Science and Technology Press; 1986. p. 176.

21. Ranarivelo Y, Skaltsounis AL, Andriantsiferana M, Tillequin F. Glycosides from Mussaenda arcuata Lam. ex Poiret leaves. Ann Pharm Fr 1990;48(5):273-7.

22. Biswanath D, Sudhan D, Santanu M, Shiho A, Nariko S, Yoshihiro H. Chemical constituents of Mussaenda incana. Indian J Chem 2005;44B:2362-6.

23. Michael D. Medicinal Plants in the South Pacific. Western Pacific Series No. 19. Geneva: WHO Regional Publications; 1998. p. 125.

24. Das P. Mass cloning of rose and Mussaenda, popular garden plants, via somatic embryogenesis. Hortic Sci Prague Czech Republ 2010;37:70-8.

25. Bhat KG. Flora of Udupi. Karnataka, India: Indian Naturalist (Regd.); 2003.

26. Murashige T, Skoog F. A revised medium for rapid growth and bioassays with tobacco tissue culture. Physiol Plant 1962;15:467-97.

27. Harborne JB. Phytochemical methods. A Guide to Modern Techniques of Plant Analysis. $2^{\text {nd }}$ ed. London: Chapman and Hall; 1973.

28. Sofowora A. Medicinal Plants and Traditional Medicine in Africa. Ibadan, Nigeria: Spectrum Books Ltd.; 1993. p. 191-289.

29. Ikram EH, Eng KH, Jalil AM, Ismail A, Idris S, Azlan A, et al. Antioxidant capacity and total phenolic content of Malaysian underutilized fruits. J Food Compos Anal 2009;22(5):388-93.

30. Sreevidya N, Mehrotra S. Spectrophotometric method for estimation of alkaloids precipitable with Dragendorff's reagent in plant materials. J AOAC Int 2003;86(6):1124-7.

31. Zishen J, Mengcheng T, Jianming W. The determination of flavonoid contents in mulberry and their scavenging affects on superoxide radicals. Food Chem 1999;64:555-9.

32. Oyaizu M. Studies on products of browning reactions: Antioxidative activities of products of browning reaction prepared from glucosamine. Jpn J Nutr 1986;44:307-15

33. Shinde UA, Phadke AS, Nair AM, Mungantiwar AA, Dikshit VJ, Saraf MN. Studies on the anti-inflammatory and analgesic activity of Cedrus deodara (Roxb.) Loud. wood oil. J Ethnopharmacol 1999;65(1):21-7.

34. Lubaina AS, Murugan K. Effect of growth regulators in callus induction, plumbagin content and indirect organogenesis of Plumbago zeylanica. Int J Pharm Pharm Sci 2012;4(1):334-6.

35. Bhagya N, Chandrashekar KR. Evaluation of plant and callus extracts of Justicia gendarussa burm. F. for phytochemicals and antioxidant activity. Int J Pharm Pharm Sci 2013;5(2):82-5.

36. Namde H, Minal W. Callus induction studies and active components and antioxidant activity investigation from leaves and callus of Tecoma stans L. Juss. ex Kunth. Res J Pharm Biol Chem Sci 2014;5(2):604-10.

37. Thalwal S, Pannu J, Gupta A. Comparison of antimicrobial activity and phytochemical constituents of in vivo and in vitro grown Amaranthus spinosus plants. Int J Pharm Pharm Sci 2013;5(3):703-7.

38. Kubmarawa D, Ajoku GA, Enworem NM, Okorie DA. Preliminary phytochemical and antimicrobial screening of 50 medicinal plants from Nigeria. Afr J Biotechnol 2007;6(14):1690-6.

39. Mensah JK, Okoli RI, Ohaju-Obodo JO, Eifediyi K. Phytochemical, nutritional and medical properties of some leafy vegetables consumed by Edo people of Nigeria. Afr J Biotechnol 2008;7(14):2304-9.

40. Tanwer BS, Vijayvergia R. Phytochemical evaluation and quantification of primary metabolites of Alangium salviifolium. Int J Pharm Bio Sci 2010;1(3):1-6.

41. Bhagya N, Chandrashekar KR, Muralidharan K, Amarnath $\mathrm{CH}$. Phytochemical analysis and antioxidant activity of in vitro cultured stem callus of Cyclea peltata. J Trop Med Plants 2012;13(2):117-23

42. Jeong GT, Woo JC, Park DH. Effect of plant growth regulators on growth and biosynthesis of phenolic compounds in genetically transformed hairy roots of Panax ginseng C. A. Meyer. Biotechnol Bioprocess Eng 2007; 12:86-91.

43. Taj Al-Deen AM. Application tissue culture technique on some medicinal and aromatic plants used in Yemen. Ph-D Thesis Faculty of Science University of Sana'a; 2010.

44. Wani M, Sharma A, Deshpande J, Mathew S, Khetmalas MB. 
Qualitative phytochemical screening of three indigenous medicinal plants. Res J Pharm Biol Chem Sci 2013;4(1):287.

45. Umesh TG. In vitro callus induction and antioxidant potential of Decalepis hamiltonii (Wight and Arn). Int J Pharm Pharm Sci 2014;6(6):452-6

46. Rami E, Patel I. Quantitative analysis of total phenols and flavonoids in in vivo and in vitro samples of Oroxylum indicum (L.) Vent. Asian J Pharm Clin Res 2015;8(2):202-6.

47. Kahkonen MP, Hopia AI, Vuorela HJ, Rauha JP, Pihlaja K, Kujala TS, et al. Antioxidant activity of plant extracts containing phenolic compounds. J Agric Food Chem 1999;47:3954-62.

48. Yang J, Gong ZC, Tan X. Induction of callus and extraction of alkaloid from Yi Mu Cao (Leonurus heterophylus Sw.) culture. Afr J Biotechnol 2008;7(8):1157-62.

49. Indrani T, Vijay KJ, Sanjeev KA, Maheshwar PT, Birendra P, Upendra KS. Quantitative spectrophotometric estimation of total alkaloids in Withania somnifera L. in vivo and in vitro. Int J Appl Biol Pharm Technol 2016;7(2):254-7.

50. Babeet ST, Neha S, Soniya C, Rekha V. In vitro preliminary phytochemical and antioxidant activity of Alangium salviifolium linn.
Int J Curr Microbiol Appl Sci 2014;3(10):864-72.

51. Duh PD, Tu YY, Yen GC. Antioxidant activity of water extract of Harng Jyur (Chrysanthemum moifolium Ramat). Lebensm Wiss Technol 1999;32(5):269-77.

52. Gordon MH. Food antioxidants. In: Hudson BJ, editor. The Mechanism of the Antioxidant Action in Vitro. London: Elsevier; 1990. p. 1-18.

53. Gulcin I, Oktay M, Kirecci E, Kufrevioglu OI. Screening of antioxidant and antimicrobial activities of anise (Pimpinella anisum L.) seed extracts. Food Chem 2003;83:371-82.

54. Deepika A, Vidya P. Comparative analysis of in vitro anti-inflammatory and in vivo and in vitro anti-arthritic activity in methanolic extract of Pluchea lanceolata Oliver and Hiern. Int $\mathrm{J}$ Biol Pharm Res 2013;4(9):676-80

55. Deepika A, Mukesh M, Neha G, Vidya P. In vitro anti-arthritic activity in methanolic extract of Cocculus hirsutus (L.) Diels. in vivo and in vitro. Int J Pharm Sci Res 2014;5(5):1957-62.

56. Taylor J, Van Staden J. Anti-inflammatory activity in extracts prepared from callus cultures of Eucomis autumnalis (Mill.) Chitt. J Plant Growth Regul 2001;34(3):331-7. 